\title{
THE DEMISE OF RACE DISTINCTIONS IN GRADUATE EDUCATION
}

\section{ROBERT C. TAYLOR*}

A recent group of cases has propelled the issue of Negro segregation in education toward a final phase of an historic struggle. For years, colored leaders and liberal white educators had futilely assailed the wall of race distinctions behind which the southern white school system had existed. The present attitude of the United States Supreme Court, however, has opened a breach in the barrier, for it appears that race distinctions in graduate and professional education, if not completely removed, are at least disappearing rapidly.

This article attempts to trace the metamorphosis of a standard of equality, a judicial measuring rod, by which the segregation of the Negro has in the past been measured and sustained. The most recent cases and sociological surveys indicate that it is questionable whether segregation, at least in the higher levels of education, can continue to exist. Finally, the possible extension of this standard of equality to the advanced schools of private institutions is investigated, for the problem of racial discrimination in universities not directly supported by the state may indeed become an important one. Any accurate prognosis is impossible, but analysis indicates that the next decision of the Supreme Court may well afford a final answer to the question whether segregation in graduate education is permissible under a Constitution which commands that no state shall deny to any person within its jurisdiction equal protection of the laws. ${ }^{1}$

\section{A Search for Substantial Equality}

Within a short period after the Civil War, legislation establishing separate schools for white and colored was

* 2nd year law, Duke University; A.B. Duke, 1949.

U.S. Constitution, Amd. XIV, sec. 1. See Frank, The Original Understanding of "Equal Protection of the Latos," 50 CoL. L. REv. 131 (1950). 
contested on constitutional grounds. ${ }^{2}$ Post Civil War philosophy in regard to educational segregation found expression in United States v. Buntin, where a United States Circuit Court held that so long as educational advantages for Negroes were in all respects "substantially equal" to those provided for white, no' denial of equal protection resulted. ${ }^{3}$ When this issue was finally presented to the Supreme Court, the rule of the Buntin case was upheld. 4 The court relied upon Plessy v. Ferguson, ${ }^{5}$ now recognized as the classic case upholding the power of a state legislature to separate the white and colored races.

Having committed themselves to a standard of "substantial equality," the courts became faced with the difficulty of interpreting it. Some courts reluctantly conceded that "substantial equality" permitted many inequalities. As late as 1937 a court brushed aside a charge of unconstitutional discrimination against colored children who, having taken and passed high school admittance examinations, were denied admission because of race and color. ${ }^{6}$ Similar suits to remove inequities had been none too successful, ${ }^{7}$

'Nelson, The Fourteenth Amendment aNd the Negro Sinoe 1920, p. 112 (1946), indicates that Amd. XIV and Art IV, sec. 2 were invoked. The equal protection clause has become, however, the almost universal ground upon which educational segregation issues have been fought out.

310 Fed. 730 (Cir. Ct. Ohio, 1882). Many later cases have been in. terpreted as laying down a rule that a state may furnish "separate but equal" educational facilities for Negroes. The two expressions are synonymous.

- Cummings v. Richmond County Board of Education, 175 U.S. 528 (1899). See also Gong Lum v. Rice, 275 U.S. 78 (1927), where the Supreme Court again affirmed the Buntin rule.

163 U.S. 537 (1896). The court emphasized that segregation was not a white judgment of colored inferiority nor was it discriminatory to restrict Negroes to colored sections. 34 MINN. L. REV. 289 (1950) reprints a brief of the Committee of Law Teachers Against Segregation in Legal Education attacking basic doctrine of the Plessy case; Cf. Note, 49 Cor. L. REv. 629 (1949).

- Williams v. Zimmerman, 172 Md. 152, 192 Atl. 353 (1937): "Possibly there might be, under some circumstances, inequalities encountered in dealing with the two races separately that would render the maintenance of the separation inconsistent with the constitutional require. ment of equal protection of the laws, but the allowance of separate treat. ment at all involves allowance of some incidental differences."

7 NexsoN, supra., note 2 at 112 et seq. 
and continued to fail until complaints concentrating upon segregation in the top echelons of education were brought to the courts.

\section{The Change to Equality in Fact}

Prior to 1935, court action invoking the Fourteenth Amendment in questions of educational opportunities for Negroes placed little or no emphasis upon provisions for collegiate, graduate and professional studies. ${ }^{8}$ In 1935, however, a young Negro resident of Baltimore sued for writ of mandamus to compel authorities of the University of Maryland to admit him to the law school. In holding that the petitioner was entitled to admission, ${ }^{9}$ the state court looked at the Maryland out-of-state scholarship act ${ }^{10}$ and decided that such scholarships did not give substantially equal educational opportunities to the Negro students receiving them. It was then but a step for the United States Supreme Court to reach the same result despite a declaration of intent by the affected state to establish an equal law school for Negroes. ${ }^{11}$ The Gaines decision, therefore, em-

${ }^{8}$ Ibid. For a contention that by 1930 Negro students were graduating from American colleges in sufficient numbers to spotlight the general absence of such facilities in southern states, see JoHnson, THE Negro College Graduate (1938). In 1944 a nation wide survey disclosed that nine southern states made no provisions whatsoever for graduate or professional training for Negroes despite the fact that such was provided at public expense for white students. United States Office of Education, National Survey of Higher Education for Negroes (1944).

- Pearson v. Murray, 169 MId. 478, 182 Atl. 590 (1936).

${ }^{10}$ Such scholarship acts usually provided for the payment of tuition fees for Negro students, who attended universities outside the state for courses offered to white students at the state university from which Negroes were excluded by law.

11 Missouri ex rel Gaines v. Canada, 305 U.S. 337, 346 (1938) : “. . . it appears that the policy of establishing a law school at Lincoln University has not yet ripened into an actual establishment, and it cannot be said that a mere declaration of purpose, still unfulfilled, is enough." Mo. Rev. Stat., 9622 provides in part: ". . . Whenever the board of curators deem it advisable they shall have the power to open any necessary school or department." This clause was enacted pursuant to the establishment of the Missouri out-of-state scholarship fund under this section. The Gaines case expressly invalidated such enactments and cited with approval the Murray case, supra., note 9. 
phasized that "substantial equality," at least on the graduate and professional level, would require the actual maintenance of separate graduate schools established for the sole use of interested and qualified Negro students.

Some states attempted to solve the problem presented by the Gaines decision through measures to provide graduate instruction within the state for colored scholars.12 But such efforts created new woes. While it was once contended that the cost of duplicate facilities might be offset by the alleged fact that Negroes require less than whites or more willingly do without, such a conclusion was belied by statistics indicating higher per capita expenditures for Negro than for white students. ${ }^{13}$ Skyrocketing educational

12 The North Carolina Commission to Study Public Schools and Colleges for Colored People recommended that "some satisfactory plan for providing graduate and professional education in the state shall be determined by the Legislature of 1939." Commission Report and Recommendations, pp. 57-61. Accordingly, in the same year a graduate school and law school were established at the North Carolina College for Negroes.

In 1935, Texas supported thirteen colleges for Negroes, six of which were standard senior colleges. Texas Dept. of Ed. Bulletin, Negro Education in Texas, XI, p. 3 (1935). Yet the Texas legislature of 1947 passed an act providing for the establishment of "The Texas State University for Negroes" to be located at Honston. Act of 1947, S.B. 140, Ch. 29, Acts. 50th Leg., Vernon's Crv. Stat. Anr., Art. 2643b. It appears that the Act of 1947 represented an attempt to evade an adverse decision by the Texas Court of Civil Appeals. See Sweatt v. Painter, 210 S.W. 2d 442 (1948), where petitioner, a Negro, was suing for admittance to the Texas University School of Law. He had applied for admission in 1946; the state established the Negro law school in 1947.

See Wheildon, Editorial Research Reports, XI, p. 824 (1947) for a discussion of the Missouri law school for Negroes.

1s Wheildon, op cit., note 12. In Missonri the per capita tax cost for students at the separate Negro law school was $\$ 695$ during the bien. ninm 1939-40; the comparable cost for white students at the University of Missouri was only $\$ 229$ per capita. 
budgets in an inflationary period ${ }^{14}$ plus small enrollment $t^{15}$ and consequently small total revenues from tuition and fees raised the price of prejudice. Then, after a brief lull, the Supreme Court announced its momentous decision ${ }^{16}$ in Sweatt $v$. Painter" and dragged the skeleton of "substantial equality" from the judicial closet in order to read the last rites:

"In accordance with these cases, petitioner may claim his full constitutional right; legal education equivalent to that offered by the State to students of other races. Such education is not available to him in a separate law school as offered by the State."18

Comparing the physical facilities of the University of Texas Law School with those of the law school for Negroes, the Chief Justice emphatically stated that:

16 To establish the Texas State University for Negroes the legislature appropriated $\$ 2,000,000$ for land, buildings and equipment and $\$ 500,000$ per annum for maintenance for the biennium ending August 31,1949 . Acts 50th Leg., \& 2, supra., note 12. In 1950 North Carolina appropriated $\$ 10,000,000$ for a building program within its colored university system. See opinion of Hayes, J. in Durham Morning Herald, p. 1 (Oct. 10, 1950). In an appeal to the United State Supreme Court, Louisiana contended that in 1950 it had appropriated $\$ 2,500$ for each Negro student at Southern Negro University. See New York Times, p. 18, col. 1 (Jan. 2, 1951). In New York Times, Sec. IV, p. 9 (Apr. 27, 1941) it is mentioned that estimates of the cost necessary to establish educational equality as between Negroes and whites in the South had ranged from an additional $\$ 400,000$ per year to a total of $\$ 56,000,000$.

${ }_{25}$ Missouri has maintained an all-Negro law school at Lincoln continuously since 1939 , in compliance with the Supreme Court ruling in the Gaines case, despite the fact that the peak attendance has been 35 students and in one year (1943) no students were enrolled. Wheildon, op cit., note 12. The University of Texas maintains a separate law school for Negroes which had a total enrollment of only 23 students in 1950. See Sweatt $\mathrm{v}$. Painter, 210 S.W. 2d 442, 444 (1948). North Carolina established a law school at the North Carolina College for Negroes in 1939 . By 1950 there were 28 students regularly attending classes. See opinion of Hayes, J. supra., note 14.

${ }^{10}$ That the ultimate decision was of importance to most of the southern states is evidenced by the fact that briefs in support of respondents were filed Amici Curiae on behalf of Arkansas, Florida, Georgia, Kentucky, Louisiana, Mississippi, North Carolina, Oklahoma, South Carolina, Tennessee, and Virginia.

17339 U.S. 629 (1950).

${ }^{38} I d$., at 635 . 
"Whether the University of Texas Law School is compared with the original or the new law school for Negroes, we cannot find substantial equality in the educational opportunities offered white and Negro law students by the state."19

Not content with a disapproval of physical inequalities, the Chief Justice stressed the significance of certain subjective attributes like reputation of the faculty, experience of the administration, position and influence of alumni and standing in the community. ${ }^{20}$ In the unanimous opinion of the court the University of Texas Law School possessed to "a far greater degree those qualities which are incapable of objective measurement but which make for greatness in a law school." 21

Had the court definitely discarded "substantial equality" in favor of the new standard, "equality in fact?" As if to dispel any uncertainty which might have clouded the Sweatt decision, the court on the same day decided McLaurin $v$. Olelahoma State Board of Regents. ${ }^{22}$ A Negro citizen of Oklahoma, possessing a master's degree, had been admitted to the graduate school of the University of Oklahoma. In comphance with state law he had been assigned, however, to a special seat in the classroom, and to special tables in the cafeteria and library. Such action, said the court, is not equality of treatment because:

"[These restrictions] signify that the State, in administering the facilities it affords for professional and graduate study, sets McLaurin apart from the other students ... Such restrictions impair and inhibit his ability to study, to engage in discussions and exchange views with other students, and in general to learn his profession." 23

Unquestionably, "equality in fact" necessitated a new educational propinquity. Nor was the enunciation of the "fact" standard a completely novel step, for lower Federal courts

\footnotetext{
${ }^{28} I d$. at 633.

20 Ibid.

Ibid.

22339 U.S. 637 (1950).

23 Id. at 641 .
} 
had previously followed a similar line of reasoning when finding discrimination in public swimming pool ${ }^{24}$ and golf course $^{25}$ cases. The Sweatt and McLaurin decisions, therefore, were closely examined by the federal courts, and a not surprising conclusion was quickly and succinctly drawn:

“. . equality of the races means equality in fact and not in theory." 26

What had been before a general trend toward equality in fact wherever tax-provided institutions existed under a system of segregation had now become a rule of law.

\section{The Incompatibility of Equality in Fact and Segregation}

The current issue to be judicially determined is whether a state can meet the equality in fact test and still insist upon segregation in the upper levels of education. Few printed opinions exist to guide those who would survey the cases; moreover, it is questionable that another decision would create more than a ripple in already troubled waters. It has been pointed out, however, that the doctrine of the Plessy case has never been expressly overruled, ${ }^{27}$ and, although agitation for such a holding has increased since the

26 Lopez v. Seccombe, 71 F. Supp. 769 (S.D. Calif. 1944). City officials had excluded citizens of Mexican and Latin descent from use of public bath house and swimming pool.

$\approx$ Law v. Mayor of Baltimore, 78 F. Supp. 346 (D. Md. 1948). An order of the Baltimore Recreation Board permitting Negro golfers to play only on a municipal course reserved exclusively for Negroes con. stituted a denial of equal protection contrary to the Fourteenth Amendment. For another golf course case see Rice $\nabla$. Arnold, 71 Sup. Ct. 77 (1950); 35 MTNN. L. REv. 399 (1951).

${ }_{20}$ Draper v. City of St. Iouis, 92 F. Supp. 546, 550 (E.D. Mo. 1950). "What are substantially equal facilities? In the Gaines case it referred to a legal education. The Gaines case did not define the terms by a discussion of particular physical facilities because the questions presented did not call for it. . . . As we read the McLaurin case the meaning of 'substantial' has been narrowed to a very fine line. Regulations that have for their purpose and do separate the races in use of taxprovided public institutions can no longer be sustained if they produce inequalities."

27 See Frank, The UNITEd States Supreare CoURT: 1949-50, 18 CHI. L. REv. 1 (1950), and 34 MINN. L. REv. 289, supra., note 5. 
Sweatt and McLaurin decisions, ${ }^{28}$ segregation remains legally unprohibited. In spite of these observations the attitude of administrative and legislative bodies, the action of individual universities and the sentiments of many professors and students furnish evidence that the concept of equality in fact is being viewed as a standard totally incompatible with segregation in graduate and professional schools.

Judicial Analysis: The recent case of McKissack v. Carmichael ${ }^{29}$ focusses upon whether the state of North Carolina could deny to Negro students admission to the state university law school by maintaining a "first rate" segregated law school for colored. ${ }^{30}$ Since the North Carolina Negro law school has enjoyed a successful existence for twelve years, the situation is somewhat distinguishable from that of the parvenu Texas law school involved in the Sweatt case. Conflicting opinions by the district judge and the three judge federal Court of Appeals exhibit opposite approaches to the issue stated above.

District Judge Hayes ${ }^{31}$ compared in detail the physical facilities and advantages of the two law schools. A careful breakdown of the opinion discloses, however, a reluctance to dwell at length upon the subjective qualities suggested by Chief Justice Vinson in Sweatt v. Painter. ${ }^{32}$ For exam-

${ }^{23}$ See 29 Neb. L. REv. 470 (1950).

${ }^{29}$ In Durham Morning Herald, p. 9 (Oct. 10, 1950) the complete text of the District Court opinion is reprinted.

so The North Carolina College for Negroes Law School was estab. lished under Public Laws (1939), Chap. 65; N.C. G.S. § 116-100.

st Judge Hayes has become a storm center for discrimination suits. In his most recent ruling he found that Durham, N.C. city schools have discriminated against Negro children; plaintiffs were held entitled to an infunction to prevent discrimination on account of race and color. The method of enforcing the infunctiou remains undecided. See Durham Sun, p. 5 (Jan. 29, 1951). In this case the basic legality of segregation was not directly in issue.

ss Supra., note 18. 
ple, the libraries, ${ }^{33}$ housing facilities ${ }^{34}$ and size of the North Carolina Negro education budget ${ }^{35}$ were discussed; but reputation of the faculty, ${ }^{36}$ experience of the administration, ${ }^{37}$ position and influence of the alumni ${ }^{38}$ and standing in the community ${ }^{30}$ were mentioned summarily. Although the Sweatt decision had speciflcally referred to those latter qualities, Judge Hayes in McKissack v. Carmichael limited the equality in fact test to the objective criteria. Prominent legal authorities ${ }^{40}$ disagreed as to the quality of the Negro law school; the opinion insisted that the segregated institutions met the equality in fact test.

The University of North Carolina law library contains approximately 64,000 volumes, two-thirds of which are not available for use. The Negro law school library contains 30,000 volumes and the opinion considers it "first rate."

Louisiana State University, in attempting to point out the equality between its law school and the separate one established for Negroes, stressed the existence of an air-conditioned library at Negro law school. The LSU law library had no air conditioning. An unimpressed three judge Federal Court cooled off this contention and ordered LSU to admit Negroes to its law school. See Southern Patriot, vol. 8, p. 9 (1950). The Supreme Court has upheld this decision. New York Times, sec. 1, p. 18 (Jan. 2, 1951).

st The opinion stated that housing was inadequate at both institutions, but that when the Negro library building is converted into a law building, then housing facilities at each institution will be "substuntially equal" for the number of students likely to attend the institutions.

3 Three paragraphs of the opinion are devoted to a discussion of North Carolina progress in maintaining segregated schools. A $\$ 4,000$, 000 budget for improvements and an annual operating budget in excess of $\$ 1,000,000$ are specificaliy mentioned.

so The Negro professors at the Negro law school are referred to only as "well-qualified" law school graduates of colored law schools.

st No mention is made of the administration except that it is headed by a full time dean.

\& This criterion emphasized in the Sweatt case, was discussed in one statement: "Its [the Negro law school's] applicants for admission to the bar are as successful in proportion to their number as those from the University of North Carolina or other law schools of the state."

$\approx$ Dismissed in one sentence.

to The dean of the Harvard Law School, a professor from the University of Chicago, and a professor from Howard University testified as to the inferiorities. A former dean of the Temple Law School, a former North Carolina Superior Court judge, two Wake Forest College professors and a former North Carolina Supreme Court justice testified to the equality of opportunities.

419 L.W. 2468 (1951), _ F.2d _. 
On appeal to the Court of Appeals for the Fourth Circuit the decision of the district court was reversed.41 This reversal was immediately interpreted to "make it impossible for any Southern State to bar otherwise qualified Negroes from white law schools, whether separate schools are provided or not.42 It is undeniable that the strong language of the Court of Appeals-stressing as it did such intangible qualities as the character of the respective students, their social contacts and influence in the profession-rejected segregation in professional education. But the court's method of reaching that result left the Plessy doctrine of separate but equal facilities theoretically untouched. Nevertheless, insofar as the standard of equality in fact is concerned, segregation in professional education has been dealt a death blow. The North Carolina Negro law school is one of the most firmly established and highly regarded of the separate graduate schools for colored students. If it cannot meet the test, no other can! Tradition and prestige acquired by white universities over periods of time are evidently not attainable by segregated institutions.

Although a petition for certiorari will probably be filed,48 the Court of Appeals emphasized that the case is not different in principle from Sweatt v. Painter. ${ }^{44}$ Accordingly, it is doubtful that the Supreme Court will feel that the case deserves detailed consideration.

Subsidiary Problems: If an assumption is made that the University of North Carolina will lose on appeal, there will be subsidiary problems arising from the admission of colored law students. For one thing, under the McLaurin ruling Negro graduate students must be permitted to eat in the

\footnotetext{
2 See Durham Morning Herald, (March 28, 1951), for comment on the opinion and reprint of important paragraphs.

t3 Apparently the trustees of the University of North Carolina do not wish to be overly intransigent. They have decided to open the doors of every university graduate school to qualified colored applicants where equal facilities are not provided by the state. See Durham Morning Herald, op. cit., note 42. However, this move was not meant to apply to the law school because the trustees still contend that equal facilities are available there for Negroes.

“ Durham Sun, p. 1 (March 27, 1951).
} 
white student dining hall. Since law students and undergraduates receive meals in the same dining hall at the state university-and apparently the general public may also eat there-persons other than law students will be thrown into unaccustomed contact with Negroes. Whether these persons will accept such contacts as calmly as law students might is doubtful.

If it is imperative for purposes of professional contactas expressed in the McLaurin case ${ }^{45}$ - that Negroes associate with their fellow white students, can this intimate association be restricted to eating and studying activities? Must not the university make available to the Negro law student the same dormitory facilities which house his white counterpart? The question of equality in dormitories is not the only housing problem. Presumably, married Negro law students seeking apartments in a white college community will be confronted with discriminatory practices which have drawn considerable comment in recent years. ${ }^{46}$

What effect will the entrance of Negroes have upon social and fraternal organizations among law students at the University of North Carolina? If these groups are sponsored by the school and in any way integrated with its educational activities, would not they too be subject to the equality in fact test? These questions, unanswerable at present, indicate practical difficulties in administering the decree of the Court of Appeals, and suggest sociological ramifications extending beyond the boundaries of the law school and its student body.

Of greater legal significance are the constitutional difficulties the University of North Carolina may encounter if it limits the admission of Negroes to "residents" of the state. ${ }^{47}$ If a non-resident Negro is refused admittance to the University of North Carolina law school, under what

is Supra., note 22, p. 645.

10 See Current Legal Attacks on Racial Restrictive Covenants, 15 CHI. L. REV. 193 (1947); Race Discrimination in Housing, 57 YALE L.J. 426 (1948); Vaughn, Restrictive Covenants Based on Race, 5 NAT. BAR J. 381 (1947).

"The University of North Carolina Board of Trustees has apparently given some indication of adopting such a policy. 
constitutional provisions may he seek to force open the university doors? Among the possibilities are: (1) the privileges and immunities clause; ${ }^{48}$ (2) the privileges or immunities clause in the Fourteenth Amendment; ${ }^{40}$ (3) the equal protection clause $;^{50}$ and (4) the due process provision of the Fourteenth Amendment.51

Under the privileges and immunities clause the citizens of each state are entitled to the privileges and immunities of the citizens of the several states. ${ }^{62}$ Can it be contended that a Negro citizen of another state is privileged to enter the University of North Carolina law school, if he is academically qualified, because citizens of North Carolina may enter? In answer, it can be pointed out that the Supreme Court does not invalidate reasonable distinctions between residents and non-residents. ${ }^{53}$ Accordingly, the university could easily contend that crowded living quarters and classrooms justify denial of admission to non-residents. Since a state may allow only residents to practice law $w^{54}$ and enter other professions, the possibility of basing a suit on the privileges and immunities clause seems remote.

Equally unfeasible is the contention that the "privileges or immunities" clause of the Fourteenth Amendment could aid the non-resident Negro plaintiff. That clause protects

\& Art. IV, § 2: "The citizens of each state shall be entitied to all the privileges and immunitles of the citizens of the several states."

- Art. XIV, \& 1: ". . . No state shall make or enforce any law which shall abridge the privileges or immunities of citizens of the United States."

${ }^{\circ}$ Art. XIV, \& 1: ". . nor shall any state deny to any pergon within its jurisdiction the equal protection of the laws."

${ }^{51}$ Art. XIV, \& 1: ". . . nor shall any state deprive any person of life, liberty or property without due process of law."

52 See Corfield v. Coryell, 4 Wash. C.C. 371 (1825). The case partially examines those privileges and immunities of citizens in the several states.

* La Tourette v. McMaster, 248 U.S. 465 (1919); Douglas v. New York, New Haven \& Hartford R. Co., 279 U.S. 377 (1929). The theory of the La Tourette case is that some residents might be non-citizens and some citizens might be non-residents; therefore, a distinction between residents and non-residents is not the same as the prohibited distinction between citizens and non-citizens. In the Douglas case overcrowded court dockets justified the discrimination against non-residents.

s* In re Rodgers, 194 Pa. 161, 46 Atl. 668 (1899). 
only those privileges or immunities that belong to citizens of the United States as distinguished from citizens of the states $; 5$ and the privilege of attending a university as a student comes not from federal sources but is given by the state. ${ }^{56}$

A more successful approach for the frustrated non-resident Negro might be through the equal protection clause. He would be especially concerned with the meaning of the phrase "within the jurisdiction", for only those persons within the jurisdiction of the state may invoke the equal protection provision. Among the most liberal interpretations of that phrase is that of the Supreme Court in Kentucky Finance Corp. v. Paramount Auto Exchange Corp., ${ }^{57}$ where a state statute requiring full examination of nonresident corporations as a condition precedent to suit in the state was held invalid. Since the non-resident corporation's attempt to sue brought it within the jurisdiction of the state, it would seem that the presence in North Carolina of a non-resident Negro seeking admission to the university law school would be sufficient to invoke the equal protection clause. And perhaps the submission of an application to the university authorities-a step similar to the filing of a complaint in the court of another state-would bring the applicant "within the jurisdiction". If the non-resident applicant is within the jurisdiction of North Carolina, is he not denied equal protection by a refusal to admit him to the law school when non-resident white applicants, similarly situated and similarly qualified, are occasionally admitted? Proof of discrimination could be furnished by declarations of university officials and by an enrollment record showing systematic exclusion of non-resident Negroes.

Unlike the equal protection clause, due process under the Fourteenth Amendment must be afforded "any person," although he may not be "within the jurisdiction." The nonresident Negro applicant could contend that discrimination in handling applications based solely on race (if he can

w Slaughter-House Cases, 16 Wall. 36 (1873).

* Hamilton v. Regents of U. of Calif., 293 U.S. 245 (1934).

o7 262 U.S. 544 (1938). 
prove it) is per se unreasonable and arbitarary state action and that such state action is a deprivation of "liberty" without "due process of law."

Administrative and Legislative Approaches: In six main proposals ${ }^{58}$ the President's Committee on Civil Rights has attacked the problem of segregation. For the first time in a governmental document, ${ }^{59}$ segregation is frankly condemned as a denial of equal educational opportunity, and it has been suggested that this report reflects the majority sentiment of the American people. ${ }^{60}$ Congress is the designated medium through which the Committee would eliminate many of the inequalities discovered, but whether or not Congress may so act depends upon certain constitutional limitations.

One writer argues that the enabling clause of the Fourteenth Amendment ${ }^{61}$ may allow Congress to increase the area of Civil Rights protection. ${ }^{62}$ If one concedes that Congress under this clause can act to remove inequalities, it would nevertheless seem that many inequalities in education, at least on the graduate level, can be eliminated by judicial action alone through test suits brought by such organizations as the NAACP. Of course, Congress, like the courts, presumably has power to deal only with state action; any legislative effort to cover private activity might lead to unconstitutionality.

6s To Secure These Rights, Report of the President's Committee on Civil Rights, (1947). The proposals are: (1) strengthening the right to safety and security of the person, (2) strengthening the right to citizenship and its privileges, (3) strengthening the right to equality of opportunity, (4) strengthening the machinery for the protection of civil rights, (5) strengthening the right to freedom of conscience and expression, and (6) a long term campaign of public education to inform the people of the civil rights to which they are entitled and which they owe one another.

59 See editorial comment, Jodrnal of Negro Education, p. 2 (Winter, 1950).

$\infty$ Ibid.

62 Amd. XIV, \& 5: "The Congress shall have power to enforce by appropriate legislation the provisions of this article."

(2 Note, State Action and the Enabling Clause of the Fourteenth Amendment, 44 IrL. L. REv. 199 (1949). Most anti-discriminatory legislation has been introduced not under this clause but in terms of interstate commerce. Thus, the Fair Employment Practice Act was advanced to the 80th Congress under the commerce clause. Id. at 206. 
On the undergraduate and high school level, Congressional efforts might accelerate the erasure of race distinctions. The real question is whether (in the event that equality in fact is found to exist between segregated schools) Congress can intervene in favor of the Negro to supersede the determination of the courts and enforce its own view of equality. What weight will the courts have to give to a Congressional determination, which derives its authority from the enabling clause of the Fourteenth Amendment, that educational facilities are unequal? The Amendment seems designed to prevent state authorities from discriminating but not to allow federal authorities to impose upon the states their own notions of what will create better harmony between the races. In other words, the mandate to Congress under the enabling clause is to strike at abuses produced by state authorities rather than to supersede judicial decisions allowing "separate but equal" facilities or to utilize state agencies to foster federal goals. These observations must be absorbed, however, with the knowledge that Congress does not seem presently inclined to deal with educational segregation.

The chief impact of educational segregation upon congressional action may be through the argument that Congress should not give federal aid to segregated schools. ${ }^{63}$ Perhaps, too, Congress may be influenced to incorporate into its grants and government contracts with southern colleges certain anti-discrimination provisions. ${ }^{64}$ Increased government grants during the present emergency might provide more leverage for such a measure; on the other hand, times of crisis are seldom vehicles for purposive social reform. At all events, congressional action of significance, though unlikely, is not definitely precluded.

Where Congress has not acted, three state legislatures have. Prior to the Sweatt and McLaurin decisions there

Chiefly on the ground that segregation is intrinsically uneconomical and that segregated school systems should reduce expenses by abolishing segregation before asking for federal funds.

os An analogy is furnished by the Wash-Healey Act providing minimum wage standards for government contracts. 
was evidence of state opposition to segregation in higher education:65 New York, New Jersey and Massachusetts have recently carried that sentiment into effect by establishing administrative agencies, ${ }^{66}$ modelled after those in fair employment practices acts, to deal with the problems of minority groups seeking admission to educational institutions.67 Such legislation leads to several questions. Can an unfair educational practice be defined? Massachusetts, New Jersey and New York have found the task difficult. ${ }^{88}$ And if the term can be defined, are private as well as tax supported institutions to be included within its scope? ${ }^{00}$ Furthermore, these questions can not arise unless the state constitution grants to the state legislature power to pass such acts. Finally, the known political facts of life in southern states lead to the belief that those states most concerned with educational segregation will not accept with alacrity fair educational practices statutes. ${ }^{70}$ The measures taken to remove discrimination in northern schools, however, like the measures suggested in the Report of the President's Committee, will undoubtedly influence any judicial determination of the validity of segregation in graduate education.

Individual University Action: It has been estimated that as a result of the Sweatt and McLaurin cases over 1,000

\footnotetext{
w Inequality of Opportunity in Higher Education: A Study of Minority Group and Related Barriers to College Admission. Report to the Temporary Commission on the Need for a State University, Albany, N. Y. (1948). College Admission Practices with Respect to Race, Religion and National Origin of Connecticut High School Graduates. Hartford: Conn. State Interracial Commission (1939).

es N. Y. Eddc. Law, \& 313 (Supp. 1950); N. J. Stat. AinN., \& 18:25 (Supp. 1949) ; MA88. ANN. Laws, c. 1510, §§ 1.5 (1950).

ef Note, 64 HARv. L. REv. 307 (1950) furnishes a comprehensive discussion of the existing state statutes.

es Ibid.

Ibid.

70 The noticeable ineffectiveness of state civil rights acts in some states indicates that state legislation is not a panacea. Statutes collected in Note, 39 Cor. L. REv. 986, 996 no. 66 (1939). Maslow, The Lano and Race Relations, 244 Awrals 75, (March 1946) advances reasons for their failure. The failure itself implies that the phlegmatic atti. tude of state legislature in the civil rights fleld will not greatly help the Negro who seeks graduate education.
} 
Negro students in seventeen southern states are attending institutions which formerly admitted only white students. ${ }^{71}$ Since these admissions are almost wholly on the graduate level, ${ }^{72}$ the actions of individual universities in admitting colored students is an important index in analyzing the decline of discrimination in graduate education.

Not all southern university action was predicated upon decisions of the United States Supreme Court. As early as 1908 little Berea College had admitted Negroes, in spite of a Kentucky Statute prohibiting the maintenance of an institution in which persons of the white and colored races were received together for instruction. Forced to discontinue this practice when the Supreme Court upheld the statute ${ }^{73}$ the school is said to have welcomed the opportunity which Sweatt and McLaurin gave it to return to its historic policy. ${ }^{74}$

Other universities have followed the court's command by letting down previous registration bars to deserving Negro graduates. Unofficial figures place the largest number of Negro graduate students on the University of Oklahoma campus, where sixty students have enrolled. ${ }^{75}$ The University of Kentucky estimated fifteen Negro graduates under its supervision; approximately the same number now attend classes at the University of Arkansas. Texas University, defendant in the Sweatt case, has accepted nineteen Negroes for graduate study; Virginia.has admitted one colored law student; Tennessee received three Negro graduates, as did Delaware; and Missouri gave nine colored students a "cordial" reception. ${ }^{7}$ In fact, only the universities of North

\footnotetext{
7 ADA World, p. 1 (Nov. 8, 1950).

T2 Ibid.

7a Berea College v. Kentucky, 211 U.S. 45 (1908).

" Southern Patriot, vol. 8, p. 9 (1950).

T3 Ibid. This periodical contains recent information on the enrollment of Negroes in all southern universities.

${ }^{76}$ Ibid. et seq. Apparently William and Mary College in Virginia has begun to admit Negroes.
} 
Carolina, ${ }^{77}$ South Carolina, Florida, ${ }^{78}$ Mississippi, Alabama, and Georgia have refused to admit Negro students to the graduate and professional schools. ${ }^{79}$

The influx of colored graduate students into state universities formerly dedicated to segregation, if it continues, may negative the importance of the equality in fact test. ${ }^{80}$ The foregoing statistics indicate that many of the southern states have by their actions virtually settled a problem which is still judicially present. Although the courts have the flnal authority to say that a segregated state university denies equality in fact, many universities have clearly anticipated such a decision. The six states retaining restricted facilities must reckon with the climate of educational opinion. On April 8, 1950, the first Southwide Conference on Discrimination in Higher Education brought together 225 administrators and educators from 116 private and public southern colleges and universities. ${ }^{81}$ Though no unanimous conclusion was reached, all principal addresses given at the conference decried the lack of adequate graduate facilities for Negroes. In a message to the conference Albert Einstein expressed the general attitude of most of the delegates:

"If an individual commits an injustice he is harassed by his conscience. But nobody is apt to feel responsible for misdeeds of a community in particular, if they are supported by old traditions. Such is the case with discrimination." 82

$\pi$ But note the recent action of the Board of Trustees in admitting a Negro to the medical school. Supra., note 43.

${ }_{78}$ On August 1, 1950 the state Supreme Court of Florida valldated a plan whereby Negroes seeking courses not avallable at the segregated Negro school could enroll at the University of Florlda temporarily. See Southern Patriot, supra., note 63.

70 ADA World, supra., note 71.

s See Jenkins, Enrollment in Negro Graduate and Professional Schools, a survey which has appeared annually in the Journal of Negro Education since 1937. The latest report, showing a complete breakdown of enrollment in all Negro graduate schools, reached a grand total of 1,362 colored advanced students. See JourNaI of NEqBo EDUOATTON, pp. 197-208 (Spring, 1950).

si See Report on Conference on Discrimination in Higher Education, Southern Conference Education Fund, (April 8, 1950).

Ibia., p. 8. 
However undeniable it is that some university officials either completely favor segregation ${ }^{83}$ or support the regional school plan,84 reports of the conference still indicate that most administrators of segregated universities were willing even before the Sweatt and McLaurin cases to search for some solution. 85 This sentiment, which grows stronger with each case, may bring increasing pressure upon the administrators of segregated schools.

Educational associations may also have some voice in settling the discrimination issue. ${ }^{86}$ The American Council on Education has adopted an affirmative program ${ }^{87}$ including the following basic points:

(1) Development of a program by the colleges themselves that would eliminate such discrimination,

(2) Enactment of legislation wherever necessary.

๕ Dr. J. Hillis Miller, President of the University of Florida, stated that ". . . segregation in higher education at the present time is in the best interest of the colored people." Tampa Bulletin (July 30, 1949).

Members of the University of North Carolina Board of Trustees expressed the conviction that the segregated Negro law school was quite in the interest of the Negro students. See Durham Morning Herald, p. 1 , (Oct. 10, 1950).

es Under this plan a Board of Control for Regional Education is set up. Its membership consists of the governors of the states in the plan and three additional appointees of each governor. Executive offices are in Atlanta, Ga., each staff contributing to the expenses required. Under the staff's direction are several consultative commissions composed of specialists for the specific area of activity concerned; these commis. sions supply the needs of the region. All decisions are made by the Board of Control and must be approved subsequently by the legislatures of the states. See Report on Discrimination, supra., note 81, pp. 40-42.

\& Ibid.

s8 It has been suggested that segregation is rapidily on the way out and that consequently Negro institutions in general will be weakened and many will die because states will put their money into non-segregated institutions. This observation was prompted by the refusal of the Southern Association of Colleges and Secondary Schools to allow the Negro colleges of the region to become members. Richmond Times Dispatch, p. 2, (Dec. 5, 1950). See Resolution V, p. 42, Proceedings of Association of Colleges and Secondary Schools (1949), for the formal request made by the Association of Colleges and Secondary Schools for Negroes.

g Journal of Negro Eddocation, p. 2 (Winter, 1950). The program was the product of a conference on discrimination in which delegates from twenty-four states participated. 
There is evidence that the pressure exerted by educational organizations may become coercive if a member of the association refuses to abolish segregation, e.g. the proposal by the American Association of Law Schools of a resolution which requires the abolition of segregation by member schools as a condition of membership. ${ }^{88}$ Presumably, this requirement would extend to both private and public schools. But these associations are at most confederations unable to enforce effectively their own pronouncements; on the other hand, whatever force they can muster is another thorn in the side of segregated schools.

Attitudes of Southern University Professors and Students: Unquestionably, the reaction of professors and students to the conflict between equality in fact and segregation will be reflected in future university action. A recent poll of southern college and university professors, completed in December of 1950, revealed that seven out of every ten teachers who replied favored immediate admission of $\mathrm{Ne}-$ groes to the graduate and professional schools of the South, without segregation. ${ }^{89}$ Every professor polled ${ }^{90}$ received a

$₫$ See Resolution on Discrimination, American Association of Law Schools, (Dec. 28, 1950).

8o JoURNAI OF NEGBo EddCATION, XIX, p. 118 (Winter, 1950). 70.5\% of the total replies favored no segregation. Only Alabama, Georgia, Mississippi, and South Carolina professors failed to vote overwhelmingly for equality in fact as opposed to segregation.

$\infty$ Ballots were sent to approximately 15,000 teachers in 14 southern institutions. Some 3,442 usable replies were received. Of these, $3134-91 \%$-were from teachers in 130 "white" institutions and 288$9 \%$-were from teachers in 25 "Negro" institutions. The trend in this poll approximated very closely the results of a similar poll of "white" state university teachers in 1948. Although the ballots stated that signatures were optional, $77 \%$ of the returns were signed, and $53 \%$ gave written reasons for their choices. A selected number of these comments are reprinted in JouBdax of NEGBo EddCation, supra., note 89, pp. 122-133.

Any poll of this sort must be discounted to some degree. For one thing, many violently anti-gegregation professors might dislike all alternatives and decide to throw away the ballot. Moreover, those who did not reply may have been apathetic, but if pressed, would have chosen one of the other three alternatives. Finally, in determining which replies were "usable" a selectivity factor may have operated upon the conductors of the poll. 
choice of four plans ${ }^{91}$ providing for more equal educational opportunities for Negroes in these fields. Although these professors comprised the faculties of private schools, it has been pointed out that a similar survey of state university professors revealed approximately the same results. ${ }^{92}$ Perhaps the inclination toward segregation diminishes in the higher intellectual strata; if so, then those instructors who will be most affected by the entrance of Negroes into graduate schools are those most willing to accept them.

Observers have noted that white students have accepted the admission of Negro students without rancor or violence. ${ }^{93}$ At the University of Mississippi, however, the student newspaper editor took the unprecedented liberty of advocating the admission of Negro students. Brief resentment flared up; a burning cross in front of his window rewarded the editor's efforts..$^{9 \pm}$ Notwithstanding this incident, a large scale student racial clash is not likely to occur where Negroes are admitted to graduate schools in small numbers. The more serious problems will arise when and if colored students flock to the state universities en masse. Yet if the students are willing to accept Negro classmates, university policies may change accordingly.

\footnotetext{
o Plan A-Open existing graduate and professional schools to Negroes without segregation. 2,412 of the total votes cast favored this plan. $68 \%$ of these teachers were from white institutions; teachers in Negro colleges voted $97 \%$ for the plan.

Plan B-Open existing graduate schools with segregation. This possibility received only 88 , or $3 \%$ of the total votes.

Plan C-Establish new graduate schools for Negroes. This plan was the least favored of all. It received only $2 \%$ of the votes.

Plan D-The Southern Governors' Plan to establish regional segregated schools for Negroes; it received 842 votes-24.5\%.

JourNal of Negro Eddcatron, supra., note 89, p. 118.

so ADA World, supra., note 71.

os Ibid. This incident was reported as a mild one. Delegates to the Southern Law Review Conference held in Knoxville, Tenn., April 13, 1951, insisted nevertheless that the display was somewhat violent. It must be recognized that many of the periodicals and newspapers cited are Negro-owned or Negro-supported, and that the view taken may place the colored student in a favorable position.
} 


\section{Extension of Equality in Fact to Private Institutions}

Since the present clash between segregation and equality in fact exists principally with regard to state-supported universities, it may be said that McKissack v. Carmichael for all practical purposes legally eliminates segregation in state graduate schools. Accordingly, state universities may expect a shift in student enrollment with colored registrants seeking the traditionally more treasured degrees of the nonsegregated state university curriculum and with dissatisfied white students seeking the more restrictive confines of the private university.

Some private institutions may be licking their chops at the thought that white students may be shunted to them from public ones as a result of the admission of Negroes to state schools. In a speech before the South Carolina Education Association, Governor James Byrnes of South Carolina expanded this idea when he asserted that public schools may be abandoned in favor of private ones if segregation in public schools is barred.95 While this view may be extreme, the probability that private universities are to become quite involved in the segregation question nevertheless suggests itself.

A. State Action: Before it is concluded that the private institution can refuse to admit Negro applicants, it would be well to examine the meaning of "private" and ask whether recent decisions have or have not expanded state action to include the activity of universities usually thought of as

\footnotetext{
as Columbia State, p. 1 (March 17, 1951). The governor's address was prompted by a segregation suit which will be argued May 28, 1951 in the federal court at Charleston, S.C. His idea seemed to be that education should be turned over to parochial schools. Undoubtedly, this would create new problems as to separation of church and state. Moreover, this state delegation of the sphere of education to parochial schools might not escape the argument that those schools had themselves become public. An analogy is found in Smith v. Allwright, 321 U.S. 649 (1944), where South Carolina attempted to preserve the white primary by turning its election machinery over to the Democratic party; the court held that the party was to be considered a state in strumentality and its discrimination involved state action. See also Rice v. Elmore, 165 F.2d 287 (4th Cir., 1947).
} 
privately operated. The rule often stated is that the Fourteenth Amendment prohibits only state action ${ }^{96}$ and that the amendment is no limit whatsoever on the power of a private institution to exclude members of a particular race or religion. ${ }^{97}$ But the crucial question is: what institutions are private? Recent decisions afford various approaches to that question.

Discriminatory state action prohibited by the Fourteenth Amendment may be of two types: (1) state originated discrimination and (2) state enforcement of privately originated discrimination.

Discrimination originating with the state may be found in the actions of state officials, in the exercise of state-conferred power and in performance of a state function. It would seem from the decisions that any discriminatory action by any state official or by any instrumentality of the state legislative, executive or judicial branches will constitute state originated discrimination. ${ }^{98}$ But this type of state action goes beyond the functioning of the three branches of state government. A corporation's performance of a state function in maintaining a "company town" may also lead to discrimination originating with the state..$^{99}$ As a major premise, then, it may be noted that the doctrine of discriminatory action originated by the state itself is an expanding one.

Some of the recent cases involve an extension of state action to include discrimination by private associations and groups, the state taking no part in the original discrimina-

${ }^{\circ}$ Civil Rights Cases, 199 U.S. 3 (1883); Shelley จ. Kraemer, 334 U.S. 1 (1948) at 13: “. . . The principle has become firmly embedded in our constitutional law that the action inhibited by the first section of the Fourteenth Amendment is only such action as may fairly be said to be that of the states."

on Booker v. College, 156 Mich. 95, 120 N.W. 589 (1909).

Ex parte Virginia, 100 U.S. 339 (1880); West Virginia state Board of Education $\nabla$. Barnette, 319 U.S. 624 (1943); Twining v. New Jersey, 211 U.S. 78 (1908).

$\infty$ Marsh $\nabla$. Alabama, 326 U.S. 501 (1946). Where exercising state conferred power, a union acting as bargaining agent for its members may be guilty of state originated discrimination. See Steele v. Louisville \& Nashville RR., 323 U.S. 192 (1944). 
tion. Thus, in Rice v. Elmore ${ }^{100}$ a political party was held to be no longer a private enterprise but to have becomebecause of its importance to the electorate-- "imbedded in the election machinery of the country ..."101 Although this case has been said to stand for the proposition that a state cannot idly allow a political party to discriminate, ${ }^{102}$ there is evidence that South Carolina had actually entered into the original discrimination. ${ }^{103}$ For this reason, a more recent decision declaring that state judicial enforcement of racial covenants is state action represents the broadest application of the Fourteenth Amendment in this field. Although the discrimination in Shelley $v$. Kraemer ${ }^{104}$ originated in private covenants, state enforcement of those covenants is prohibited because:
"State action, as that phrase is understood for the purposes of the Fourteenth Amendment, refers to exertion of state power in all forms. And when the effect of that action is to deny rights subject to the protection of the Fourteenth Amendment, it is the obligation of this court to enforce the consti- tutional commands."105

Carried to a theoretical extreme the doctrine of state action might be limitless, so that every action within the state would be state action. Hobbes maintained that the

${ }^{100} 165$ F.2d 287 (4th Cir., 1947).

${ }^{101} I d$. at 389: ". . . political parties have become in effect state in. stitutions, governmental agencies through which sovereign power is exercised by the people."

${ }^{102}$ See Note, State Action Within the Meaning of the Fourteenth Amendment of the Federal Constitution: The Stuyvesant Case, 23 TEMPLE L. Q. 209 (1949).

103 In 1944 the Supreme Court had held in Smith V. Allwright, 321 J.S. 649 , that the right to vote in a primary election held under state law might not be denied on the ground of race or color. Immediately following this decision, the then Governor of South Carolina convened the state legislature and recommended that it repeal all laws with relation to primaries with the avowed purpose of preventing voting by Negroes in the Democratic primaries of the state. Pursuant to this recommendation, the primary laws of the state were repealed and the Democratic primary was conducted thereafter under rules prescribed by the Democratic party. See Rice $\nabla$. Elmore, supra., note 11, p. 388.

${ }^{104} 334$ U.S. 1 (1948).

100 Ida. at 20. 
state existed to protect men from the miserable "state of nature"108 and that the state alone had power to act in all matters of information and education. ${ }^{107}$ Other totalitarian thinkers have shared this political monism. They have agreed with Hobbes that the only meaning in life of any group is in terms of the state and that all groups in one sense are creatures of the state. But despite the substitution of "Welfare" for "United" States, such a totalitarian approach would probably not be accepted by the Supreme Court. Moreover, for state action to have any meaning as a constitutional concept, it must be an instrument of exclusion as well as of inclusion; for if state action becomes all-inclusive, then as a legal doctrine it becomes superfluous. Thus, the real problem is to attempt a microscopic analysis and to ask which characteristics of a private institution might cause its discriminatory actions to be viewed either as discrimination originating with the state or as private discrimination enforced by the state.

Corporate Charters: To cite only one example Duke University, a privately-endowed institution, obtained its corporate charter under the constitution ${ }^{188}$ and laws ${ }^{109}$ of North Carolina. Since a corporate charter entitles a group to special privileges-among them limited liability, perpetual

jos See Woodbridge, The PhIlosophy of Hobbes; SkLectrons faom Leviathan, (1903).

${ }_{107}$ Id. at 333: "It is annexed to the sovereignty, to be judge of what opinions and doctrines are averse, and what conducing to peace; and consequently, on what occasions, how far, and what men are to be trusted withal, in speaking to multitudes of people; and who shall examine the doctrines of all books before they be published."

${ }^{103}$ Art. VIII, § 1 of the Const: of North Carolina provides: "No corporation shall be created nor shall its charter be extended, altered, or amended by special act, except corporations for charitable, educational, penal, or reformatory purposes that are to be and remain under the patronage and control of the State; but the General Assembly shall provide by general laws for the chartering and organization of all corporations and for amending, extending and forfeitures of all charters, except those above permitted by special act. All such general laws and special acts may be altered from time to time or repealed; and the General Assembly may at any time by special act repeal the charter of any corporation."

t00 See N.C. G.S., $\S 55-2$, relating to the formation and organization of corporations. 
existence and the right to sue-the awarding of such privileges is obviously state action. It is arguable, then, that any discrimination practiced by the university is discrimination originating with the state by means of the grant of the corporate charter. The piercing question, of course, is whether the acts of the university in discriminating against Negroes are acts properly classified as flowing from state conferred power. If it can be shown that such university action is actually an exercise of state conferred power, or is the action of a state instrumentality, then the discrimination can be attacked under the Fourteenth Amendment.

An argument which implies that the activity of a corporation is state action must of necessity be a drastic one, if the basis of such an argument is the issuance of a corporate charter. Particularly is it extreme as applied to a private university. The privilege of limited liability is of less value to universities than to profit-conscious corporations because the university is not engaged in activities that are likely to create tort liabilities. As to the privilege of perpetual existence, the same advantage might be obtained without incorporation by establishing a charitable trust to carry on university activities. ${ }^{110}$ The awarding of these privileges to educational institutions, therefore, should not be viewed dogmatically as a grant of state power. ${ }^{111}$

Tax Exemptions and Subsidies: It has been suggested that a privately endowed classical college has become almost a government university by virtue of the tax and subsidy status allowed these institutions by the federal and state

210 See 3 Scott, TBUSTB $\$ 365$ (1939). A charitable trust is recognized as an exception to the rule against perpetuities. Would judicial consideration of such a doctrine by a state court be interpreted also as state action, thus bringing the trust within the scope of the Fourteenth Amendment limitations?

211 But under a contrary view does the state approve the discrimination by failing to withdraw the corporate charter? Could a Negro or some other citizen bring quo warranto to compel the forfelture of the charter?

112 See Westin, Segregation and Discrimination in Higher Education, 10 IUWYERS' GUID REv. 213 (1950). Footnote 61 lists illustrations of government grants and tax exemptions. 
governments. ${ }^{112}$ If this premise is accepted, it is arguable that discrimination by a subsidized private institution is, in effect, the action of a state instrumentality performing a state function. That private institutions receive tax exemptions from the state is unquestionably true. North Carolina, like most other states, exempts private universities from state income tax, ${ }^{113}$ real property tax ${ }^{114}$ and gift tax on gifts made to educational organizations. ${ }^{115}$ To determine whether these exemptions are subsidies, however, the true tax status of a privately endowed school must be examined. The vaunted exemption from income tax is valueless, for few colleges realize any net income; expenses often, if not usually, exceed revenues. ${ }^{116}$ In addition, since a gift tax is normally paid by the donor and not by the donee, the gift tax exemption is of no great advantage other than to encourage voluntary contributions made at the will of the individual. Finally, there is no exemption from the state sales tax. ${ }^{117}$ Only the exemption from real property taxes

${ }^{113}$ N.C. G.S., $\S \S 105-138$ (1950): "The following organization shall be exempt from [income] taxation nnder this article: 3 . Cemetery corporations and corporations organized for religions, charitable, scientific, or educational purposes, no part of the net earnings of which inures to the benefit of any private stockholder or individual."

I1 N.C. G.S., \$§ 105-296 (1950): "The following real property, and no other, shall be exempted from taxation: (4) Bulldings, with the land actually occupied, wholly devoted to educational purposes, belonging to, actually and exclusively occupied and used for public libraries, colleges, academies, industrial schools, seminaries, or any other institution of learning, together with such additional adjacent land owned by such libraries and educational institutions as may be reasonably necessary for the convenient use of such building, and also bnildings thereon used as residences by the officers or instructors of such educational institutions."

115 N.C. G.S., $\$ \S 105-188$ (1950): "It is expressly provided, however, that the tax levied in this article shall not apply to so much of said property as shall so pass exclusively: (2) to or for the exclusive benefit of charitable, education, or religious organizations located within this State, no part of the net earnings of which inures to the benefit of any private shareholder or individual."

C. N.C. G.S. \& 105-147(9) (1950) (income tax deduction for charitable contribution).

110 This statement can be confirmed by any alumnus who has received university pleas for gifts to meet additional expenses.

w: N.C. G.S., §§ $105-164$ to $105-187$ (1950). 
lends strong support to the argument that the state thereby "subsidizes" private institutions.

The usual understanding of subsidy is that the term refers not to an exemption but to a specific grant from the government to aid the educational program. ${ }^{118}$ An excellent example of this definition is the annual appropriation of federal funds to endow and maintain state agricultural and mechanical colleges. ${ }^{110}$ Federal funds are also made available to private universities, but the suggestion that those schools are being subsidized is dispelled by the financial statements of those institutions. The Duke University Financial Report for the fiscal year ended June 30, 1950, showed that no revenues of any sort were received from the state and that total receipts from the federal government amounted to only $8 \%$ (approximate) of total revenue. ${ }^{120}$ The United States Government specified each project to be undertaken with the funds, which were distributed on either

${ }^{218}$ In Norris 7. Mayor \& City Council of Baltimore, 78 F. Supp. 451 (D. Ma. 1948), a privately owned nonprofit art school receiving an annual subsidy from the city of Baltimore and the State of Maryland rejected a Negro applicant in accordance with a policy of segregation. Held; such discrimination is not state action becauise the institution is private, not public. The decision has been criticized in 62 HABV. $L$. REv. 126 (1948).

218 U.S.C.A., § 322 . The statute sanctions the establishment of separate but equal facilities. $\S 323$ et seq.

120 Bulletin of Duke University, Financial Report, 1949-50, at 14: Condensed Statement of Revenue and Fxpenditures:

Total Revenue $\$ 6,999,362.39$

Schedule F-Government Gifts and Grants for Research:

United States Army-Contracts $125,234.66$

U.S. Atomic Energy Comm._Contracts__ 20,146.75

United States Navy-Contracts___ $\mathbf{7 7 , 6 9 6 . 3 9}$

United States Public Health Service___ 228,557.96

United States Senate $\quad 1,000.00$

United States Veterans Adm.-Contracts__ 4,322.48

$456,958.24$

Schedule G-Government Grants for Training Programs:

Federal Security Agency-Contracts ____ $\mathbf{4 1 , 3 7 5 . 0 0}$

$\begin{array}{rr}\text { United States Army } & 600.00\end{array}$

U. S. Atomic Energy Comm._Contracts__ 10,560.73

United States Pubilc Health Service___ $77,730.18$

$130,265.91$

Total Government Revenue

$\$ 587,224.15$ 
a cost-reimbursement ${ }^{121}$ or grant-in-aid ${ }^{122}$ basis. It is difficult to visualize a non-profit government contract as a subsidy supporting the private institution which receives it. Since no financial aid is received from the state, only with considerable imagination can it be said that the private school is a state instrumentality performing a state function. Nor is this view supported by any aid which the university might receive from the federal government. To say that federal grants reduce private universities to government instrumentalities within the Fifth Amendment and that state tax exemptions bring the endowed school within the state action concept of the Fourteenth Amendment is to distort the wording of the Constitution. A tax exemption is not yet grounds to find that discrimination by a private school is state originated.

Charitable Immunity from Tort: The thorough examination in Shelley $v$. Kraemer of judicial enforcement proceedings presents an additional possibility through which the discrimination of private universities can be brought within the scope of "state action." There is no legal doubt that the action of state courts and judicial officers in their

123 The university, upon completion of the designated project, is reimbursed by the government for the actual cost of performing the coutract. To the extent that private institutions are doing government work on this basis, the institution is subsidizing the government. Chief beuefits to the private institution could only be in terms of spreading overhead and avolding cut-backs. Whether these advantages exist will depend on what is cousidered "cost" under the contract. If there is no appreciable reduction of overhead and other operating expeuses and if no other benefit is derived from the government contract, then the subsidy argument falls.

102 A sum is granted to accelerate a university program already under way. See 7 U.S.C.A., supra., note 119. Such funds are applied to the development of the part of the program which the government designates. 
official capacities is to be regarded as action of the state. ${ }^{123}$ This issue is closed. But is a state court's refusal to consider tort claims against charitable institutions, such as private universities which refuse to admit Negroes, a state enforcement of privately originating discrimination? If the act of a state court, "in authoritatively construing and enforcing its laws, is the act of the State," 124 it is arguable that the adherence of a state court to the common law doctrine of charitable immunity 125 is a construction and enforcement of state law which, when applied to a discriminating university, involves state enforcement of private discrimination. A close reading of the Shelley case, however, suggests a caveat. As the court pointed out there, "The difference between judicial enforcement and non-enforcement of the restrictive covenants is the difference to petitioners between being denied rights of property available to other members of the community and being accorded full enjoyment of those rights on an equal footing."120 The analogy from this case to denial of a tort suit against a private university which discriminates in its selection of students is incomplete. In the latter situation the judicial interpretation affects in no wise the barred student, but

123 Shelley v. Kraemer, 334 U.S. 1 (1948); Civil Rights Cases, 109 U.S. 3 (1883) ; Ex parte Virginia, 100 U.S. 339 (1880); Virginia V. Rives, 100 U.S. 313 (1880); Brinkerhoff-Faris Trust and Savings Co. v. Hill, 281 U.S. 673 (1930); Martin v. Texas, 200 U.S. 316 (1906); Raymond v. Chicago Union Traction Co., 207 U.S. 20 (1907); Home Telephone and Telegraph Co. v. Los Angeles, 227 U.S. 278 (1913); Prudential Insurance Co. v. Cheek, 259 U.S. 530 (1922); American Railway Express Co. v. Kentucky, 273 U.S. 269 (1927) ; Mooney v. Holohan, 294 U.S. 103 (1935); Hansberry v. Lee, 311 U.S. 32 (1940).

224 Twining v. New Jersey, 211 U.S. 78, 90-91 (1908). See also American Federation of Labor v. Swing, 312 U.S. 321 (1941), where enforcement by state courts of the common-law policy of the state, which resulted in the restraining of peaceful picketing, was held to be a state action of the sort prohibited by the Fourteenth Amendment's guaranties of freedom of discussion. See also Bakery Drivers v. Wohl, 315 U.S. 769 (1942).

${ }_{15 s}$ North Carolina recognizes charitable immunity. Green v. Biggs, 167 N.C. 417 (1914); Hoke v. Glenn, 167 N.C. 594 (1914). That this represents the majority view is stated in Herndon v. Massey, 217 N.C. 610, 613 (1940).

128 Shelley v. Kraemer, supra., note 104, p. 19. 
instead only precludes recognition of the rights of the tort claimant. Consequently, despite the benefit to the university from the precluding of expensive judgments, tort immunity seems insufficient to invoke the rationale of Shelley v. Kraemer.

Public Utility: Application of the equality in fact theory to private universities through an extended concept of state originated discrimination raises one final possibility. It is arguable that education is affected with a public interest and so closely tied to the welfare of the state that any educational institution within the state is, in effect, a public utility. ${ }^{127}$ It is then suggested that because of the state's power to regulate a public utility, the private university is effectively reduced to a subsidiary of the state. Private handling of a state function (education) is involved, and any discrimination practiced by the private university becomes state originated.

The public utility argument would be especially strong in the lower strata of education; some rudimentary education would seem essential to the performance of the role of citizenship, for, without it, one is not qualified to vote or adequately to serve the country. On the other hand, advanced education, while desirable, is not as imperative either from the point of view of the state or of the individual. And so it would be difficult to apply the public utility notion to a private university.

Perhaps the public utility concept would afford a state legislature constitutional authority for passing a fair educational practices act. Such an act would merely enforce the common law obligation of a public utility to give nondiscriminatory service to all. But it is questionable that the failure to pass such a statute can be state originated

127 Is there any fundamental distinction between public and private agencies? See Barnett, What is State Action under the Fourteenth, Fifteenth and Nineteenth Amendments of the Constitution, 24 ORE. L. REv. 227 (1945). In Munn v. Illinois, 94 U.S. 113 (1877), the court suggested that many "private" businesses so substantially affect the community that the law considers them "public" for the purposes of state regulation. 
discrimination. Under a view that state inaction can be action, the judiciary would have to overturn any legislative choice of a "hands-off" approach and undertake an extensive program to remove discrimination by judicial decree. The problem of judicial administration of such a court-created fair educational practice act is another reason for favoring a narrower view of state originated discrimination.

The approaches suggested in bringing discrimination by private universities within the realm of state action are both interesting and varied. State originated discrimination is not a static concept, nor is state enforcement of private discrimination limited in its application. Although judicial expansion of either view may change the law at present, state action under the Fourteenth Amendment apparently does not require private universities to change their policies to meet the equality in fact test.

B. Anti-Trust Laws:128 The Fourteenth Amendment is not the only medium through which equality in fact can be extended to private institutions. The Sherman Anti-Trust Act prohibits contracts, combinations or conspiracies in restraint of trade or commerce among the states or foreign nations. ${ }^{129}$ A statute prohibiting restraints of "trade or commerce" does not at first suggest a protection of civil liberties; yet it has been advanced that this implication is derived from Magna Charta, ${ }^{130}$ and such a view has been discussed in the courts. ${ }^{131}$ Cases arising under the act show

${ }^{203}$ See Marcus, Civil Rights and the Anti-Trust Lavos, 18 CHx. L. REv. 171 (1951), for an exhaustive treatment of the entire subject.

12026 Stat. 209 (1890), 15 U.S.C.A., \& 1 (1941).

${ }^{180}$ See Holdsworth, Industrial Combinations and the Law in the Eighteenth Century, 18 MnNN. L. REv. 369 (1934).

${ }^{131}$ Butchers' Union Co. v. Crescent City Co., 111 U.S. 746 (1884) at 757: "The common business and callings of life, the ordinary trades and pursuits, which are innocuous in themselves, and have been fol. lowed in all communities from time immemorial, must therefore, be free in this country to all alike upon the same conditions. The right to pursue them, without let or hindrance, except that which is applied to all persons of the same age, sex and condition, is a distinguishlng privilege of all citizens of the United States, and an essential element of that freedom which they cleim as their birthright." Compare Allgeyer v. Louisiana, 165 U.S. 578 (1897). 
a continual widening of the area embraced by the statutory prohibition against restraint of trade ${ }^{132}$ with the result that the bounds within which the statute is to operate are set by the standard of harm to the common good, ${ }^{133}$ as well as by the economic freedom of the individual. By an even more liberal construction of the anti-trust laws it has been argued that discrimination stemming from private groups in control of higher educational facilities falls within the statutory grasp of the Sherman Act. ${ }^{134}$ If the argument is sound, the board of trustees of a privately endowed college which denies admission to Negroes may find itself to be a group which has "conspired to restrain trade or commerce."

To invoke the anti-trust laws, however, a plaintiff must find some right infringed which is protected by the act. A private university which discriminates in its choice of students cannot be attacked unless it has contracted, combined or conspired "in restraint of trade or commerce." One may concede that there is a right to an education, ${ }^{135}$ and that private universities are often guilty of discrimination, ${ }^{136}$ but it nevertheless does not follow that the deprivation of an educational right is a conspiracy in restraint of trade. Unquestionably, there is sufficient group activity in the action of a private university board of trustees to support

\footnotetext{
122 Appalachian Coals, Inc. จ. U.S., 288 U.S. 344 (1933); Diener Cleaners, Inc. v. Vogue D.C. Co., 11 F.A.D. 479 (D.C., 1930).

113 United States V. American Tobacco Co., 221 U.S. 183 (1911).

I3 See Marcus, supra, note 128, at 205.

is Universal Declaration of Human Rights, Art. 27. See also The Selected Addresses of Franklin D. Roosevelt 387 (1946), Annual Message of the President to Congress, Jan. 11, 1944.

jo Mangum, The Legal Status of the Negro, IV (1940); Forster, A Measure of Freedodr (1950); Prevention of Discrimination in Private EdUcatonal Institutions, 47 Col. L. Rev. 821 (1947).

It has been asserted that in the East a majority of application blanks used by colleges continued to include discriminatory questions which bore no relation to educational qualifications. See Anti-Defamation League of B'nai B'rith, Anti-Semitism in the United States in 1947, p. 28 (1948). Cf. Myrdal, An Asrenicax Dmenrara pp. 633, 1367 (1944).
} 
a finding of conspiracy, ${ }^{137}$ but only with great legal imagination can a board's administrative policies be transformed into illegal conspiracies in restraint of "trade."138 Evidently, discrimination in graduate education is not per se a conspiracy or combination in restraint of interstate commerce. The language of the Sherman Act, broad though it is, is not at present prone to such an interpretation.

\section{Conclusion}

No longer will the Constitution permit a state to educate qualified Negroes in separate graduate and professional schools. The Supreme Court has elevated the standard of equality to a height that no segregated graduate school can attain. Some states have recognized the sole solution and have admitted Negro graduates to the state universities;

${ }^{137}$ Nash v. United States, 229 U.S. 373 (1913). An anti-trust case is made out by proof of the fact of conspiracy; and if the necessary consequences of a conspiracy is to produce a result which the anti-trust laws are designed to prevent, tbe conspirators are charged with the result. United States v. Patten, 226 U.S. 525 (1913). Either the Board of Trustees or the university corporation could probably be brought within the act, if sufficient restraint of trade or conspiracy could be found.

${ }^{133}$ Applying equality in fact to private institutions by means of the anti-trust laws is not completely precluded by the foregoing analysis. Notice has been taken that higher education is becoming increasingly important as the primary stepping stone to the making of a livelihood. See Marcus, supra., note 128, at 208. This is especially true in the professions. Graduation from an accredited law school is often a requisite for admission to a state bar association. For a typical requirement see Rules and Regnlations of the North Carolina State Bar, January, 1943. The medical profession is even more discriminatory in its educational requirements. See Group Practice Versus the American Medical Association, 18 Fortune, No. 5 (Nov., 1938). The Sherman Act has alrcady been construed to apply to combinations of professions or services in restraint of trade. Rogers v. Poteet, 355 Mo. 986, 199 S.W. 2d 378 (1947); American Lesgue Baseball Club of Chicago $\nabla$. Chase, 86 N.Y. Misc. 441,149 N.Y. Supp. 6 (1941). It is feasible, therefore, to conclude that the exclusion of Negroes from a professional association is a conspiracy in restraint of trade. See Marcus, ibid. Since private graduate and professional schools contribute greatly to the flow of prospective professional practitioners from universities to careers, it may be possible to trace the "pattern of discrimination" from the private association to the private university and then to apply the Sherman Act. 
others will undoubtedly follow. As discrimination in state universities vanishes, private institutions will be drawn into the conflict between the new standard of "equality in fact" and the old conception of separation of the races. The coming legal campaigns in the war against segregation will determine whether the defenses available to "private" graduate schools are less vulnerable than those of the state universities. 